\title{
Correction: A Computational Study on Iron Oxide Magnetite Nanoparticles As Adsorbents of Anionic Pollutants
}

\author{
Farzaneh Zanjanchi ${ }^{1}$
}

Published online: 2 March 2022

(c) The Minerals, Metals \& Materials Society 2022

\section{Correction to: Journal of Electronic Materials https://doi.org/10.1007/s11664-022-09450-9}

The original online version of this article was revised. Reference citations in the text were corrected, as well as the renumbering of references in the reference list.

Publisher's Note Springer Nature remains neutral with regard to jurisdictional claims in published maps and institutional affiliations.

The original article can be found online at https://doi.org/10.1007/ s11664-022-09450-9.

Farzaneh Zanjanchi

fzanjanchi@yahoo.com

1 Department of Chemistry, Takestan Branch, Islamic Azad University, Takestan, Iran 